\title{
Thermal Behavior and Spectroscopic Study of Neutral and Cationic Mononuclear Cyclopalladated Compounds
}

\author{
Sandra R. Ananias and Antonio E. Mauro* \\ Instituto de Química, Universidade Estadual Paulista, CP 355, 14.801-970 Araraquara - SP, Brazil
}

\begin{abstract}
As reações do ciclopaladado catiônico $\left[\mathrm{Pd}(\mathrm{N}, \mathrm{C}-\mathrm{dmba})(\mathrm{MeCN})_{2}\right]\left(\mathrm{NO}_{3}\right)(\mathbf{1})(\mathrm{dmba}=N, N$ dimetilbenzilamina), como os pré-ligantes 3,5-dimetilpirazol (Hdmpz); 2-quinolinatiol (qnSH) e 1,1'-bis(difenilfosfina)ferroceno (dppf) levaram à formação dos compostos, respectivamente, $\left[\mathrm{Pd}(\mathrm{N}, \mathrm{C}-\mathrm{dmba})(\mathrm{Hdmpz})\left(\mathrm{ONO}_{2}\right)\right] 0.5 \mathrm{CH}_{2} \mathrm{Cl}_{2}(2),\left[\mathrm{Pd}(\mathrm{N}, \mathrm{C}-\mathrm{dmba})(\mathrm{qnSH})\left(\mathrm{ONO}_{2}\right)\right] \quad 0.5 \mathrm{CH}_{2} \mathrm{Cl}_{2}(3)$ e $[\mathrm{Pd}(\mathrm{N}, \mathrm{C}-\mathrm{dmba})(\mathrm{dppf})]\left(\mathrm{NO}_{3}\right)(\mathbf{4})$. As novas espécies mononucleares $\mathbf{2}, \mathbf{3}$ e $\mathbf{4}$ foram caracterizadas através de análise elementar, espectroscopia de absorção na região do infravermelho, espectroscopia de ressonância magnética nuclear e análise termogravimétrica. Os dados da espectroscopia no IV mostram bandas consistentes com o grupo nitrato monodentado nos casos dos compostos $\mathbf{2}$ e $\mathbf{3}$ e nitrato iônico no da espécie 4. Os dados de $\mathrm{RMN}$ de ${ }^{13} \mathrm{C}$ e ${ }^{1} \mathrm{H}$ confirmam que os respectivos ligantes encontram-se coordenados ao átomo de paládio e o $\mathrm{RMN}$ de ${ }^{31} \mathrm{P}\left\{{ }^{1} \mathrm{H}\right\}$ de $\mathbf{4}$ evidencia claramente a ocorrência de três espécies ciclopaladadas em solução, com o dppf atuando como ligante ponte em duas e como um quelato em uma. O comportamento térmico dos compostos 1-4 sugere que o composto 2 é o mais estável. Os resultados da difratometria de raios X, método do pó, confirmam a formação dos seguintes resíduos finais de termodecomposição: $\mathrm{PdO}$ para as espécies $\mathbf{1}$ e 2, uma mistura de $\mathrm{PdO}$ e $\mathrm{Fe}_{2}\left(\mathrm{PO}_{4}\right)_{3}$ para 4 e, $\mathrm{Pd}_{2} \mathrm{OSO}_{4}$ para o composto 3 .
\end{abstract}

The reactions of the precursor $\left[\mathrm{Pd}(\mathrm{N}, \mathrm{C}-\mathrm{dmba})(\mathrm{MeCN})_{2}\right]\left(\mathrm{NO}_{3}\right)(\mathbf{1})(\mathrm{dmba}=N, N-$ dimethylbenzylamine), with the proligands 3,5-dimethylpyrazole (Hdmpz), 2-quinolinethiol (qnSH) and 1,1'-bis(diphenylphosphine)ferrocene (dppf) afforded the compounds [Pd(N,Cdmba) $\left.(\mathrm{Hdmpz})\left(\mathrm{ONO}_{2}\right)\right] 0.5 \mathrm{CH}_{2} \mathrm{Cl}_{2}(2),\left[\mathrm{Pd}(\mathrm{N}, \mathrm{C}-\mathrm{dmba})(\mathrm{qnSH})\left(\mathrm{ONO}_{2}\right)\right] \quad 0.5 \mathrm{CH}_{2} \mathrm{Cl}_{2}(3)$ and $[\mathrm{Pd}(\mathrm{N}, \mathrm{C}-\mathrm{dmba})(\mathrm{dppf})]\left(\mathrm{NO}_{3}\right)(\mathbf{4})$, respectively. The mononuclear species $\mathbf{2 , 3}$ and $\mathbf{4}$ were characterized by elemental analysis, infrared spectroscopy, NMR and thermogravimetric analysis. The IR spectra show bands which are consistent with terminal monodentate nitrate group for $\mathbf{2 - 3}$ and ionic nitrate for 4. The ${ }^{1} \mathrm{H}$ and ${ }^{13} \mathrm{C}$ NMR data confirm that coordination of the organic ligands has occurred and the ${ }^{31} \mathrm{P}\left\{{ }^{1} \mathrm{H}\right\}$ NMR data for $\mathbf{4}$ clearly evidences the occurrence in solution of three cyclopalladated species with the dppf acting as a bridging ligand in two cases and as a chelate in one. The thermal behavior of compounds 1-4 suggests that complex $\mathbf{2}$ is the most stable. The X-ray diffractometry results show the formation of $\mathrm{PdO}$ from 1 and $2, \mathrm{Pd}_{2} \mathrm{OSO}_{4}$ from $\mathbf{3}$, and of a mixture of $\mathrm{PdO}$ and $\mathrm{Fe}_{2}\left(\mathrm{PO}_{4}\right)_{3}$ from 4, as final decomposition products.

Keywords: cyclopalladated species, IR and NMR spectroscopy, thermogravimetric analysis

\section{Introduction}

The intramolecular C-H activation, or cyclometallation reaction, which is a major achievement of organometallic chemistry, ${ }^{1}$ provides access to metalacyclic derivatives of the transition metals. ${ }^{2}$ Many papers dealing with this subject were reported in the literature during the last decade $^{3}$ demonstrating the enormous interest suscitated particularly by the cyclopalladated compounds. These

\footnotetext{
*e-mail: mauro@iq.unesp.br
}

complexes have provided a stimulating area of research and they can be found in interesting uses such as in organic synthesis, ${ }^{4}$ liquid crystals, ${ }^{5}$ photochemistry, ${ }^{6}$ catalysis ${ }^{7}$ and as anti-tumor agents. ${ }^{8}$

We have recently described the synthesis, reactivity and application as anti-tumor agents of palladium cyclometallated compounds ${ }^{9}$ and in the framework of our current research on this class of compounds we report in the present paper the reactivity of the compound $[\mathrm{Pd}(\mathrm{N}, \mathrm{C}-$ $\left.\mathrm{dmba})(\mathrm{MeCN})_{2}\right]\left(\mathrm{NO}_{3}\right)(\mathbf{1})(\mathrm{dmba}=N, N$-dimethylbenzylamine) towards the proligands 3,5-dimethylpyrazole (Hdmpz), 2-quinolinethiol (qnSH) and 1,1'-bis(diphenyl- 
phosphine)ferrocene (dppf). The choice of these molecules was due to their versatility as ligands, ${ }^{10}$ since they exhibit various modes of bonding to metallic centres and also to the biological and catalytic importance of their complexes. All the new compounds obtained, namely [Pd(N,C$\left.\mathrm{dmba})(\mathrm{Hdmpz})\left(\mathrm{ONO}_{2}\right)\right] 0.5 \mathrm{CH}_{2} \mathrm{Cl}_{2}$ (2), $[\mathrm{Pd}(\mathrm{N}, \mathrm{C}-$ $\left.\mathrm{dmba})(\mathrm{qnSH})\left(\mathrm{ONO}_{2}\right)\right] 0.5 \mathrm{CH}_{2} \mathrm{Cl}_{2}(3)$ and $[\mathrm{Pd}(\mathrm{N}, \mathrm{C}-$ dmba)(dppf)] $\left(\mathrm{NO}_{3}\right)$ (4) are mononuclear species. These compounds were characterized by elemental analysis, IR and NMR spectroscopy. In addition they were investigated by thermogravimetric analysis and the final decomposition products were identified by X-ray powder diffractometry.

\section{Experimental}

Materials

All the syntheses were carried out at room temperature and the reagents were employed without further purification. $\left[\mathrm{Pd}(\mathrm{N}, \mathrm{C}-\mathrm{dmba})(\mathrm{MeCN})_{2}\right]\left(\mathrm{NO}_{3}\right)$ (1) was prepared as described in the literature. ${ }^{11}$

\section{Syntheses}

$\left[\mathrm{Pd}\left(\mathrm{N}, \mathrm{C}\right.\right.$-dmba) $\left.(\mathrm{Hdmpz})\left(\mathrm{ONO}_{2}\right)\right] 0.5 \mathrm{CH}_{2} \mathrm{Cl}_{2}$ (2). To a solution of $0.10 \mathrm{~g} \quad(0.26 \mathrm{mmol})$ of $[\mathrm{Pd}(\mathrm{N}, \mathrm{C}-$ dmba) $\left.(\mathrm{MeCN})_{2}\right]\left(\mathrm{NO}_{3}\right)(\mathbf{1})$ in $10 \mathrm{~mL}$ of dichloromethane were added $0.049 \mathrm{~g}(0.52 \mathrm{mmol})$ of 3,5-dimethylpyrazole (Hdmpz) in $5 \mathrm{~mL}$ of dichloromethane. The resulting colorless solution was stirred for $1 \mathrm{~h}$; it was then concentrated under reduced pressure and the addition of a mixture of diethyl ether/pentane (1:1) afforded a white solid. The compound was filtered off, washed thoroughly with pentane and dried in vacuo. Recrystallization from a mixture of dichloromethane/ acetone $(1: 1)$ gave a white solid. Yield: $0.087 \mathrm{~g}, 90 \%$. (Found: C, 42.9; H, 4.5; N, 14.8 . $\mathrm{C}_{14,5} \mathrm{H}_{21} \mathrm{~N}_{4} \mathrm{O}_{3}$ ClPd calcd.: C, 42.8; H, 4.8; N, 14.7\%).

$\left[\mathrm{Pd}\left(\mathrm{N}, \mathrm{C}\right.\right.$-dmba) $\left.(q n \mathrm{SH})\left(\mathrm{ONO}_{2}\right)\right] 0.5 \mathrm{CH}_{2} \mathrm{Cl}_{2}$ (3). To a solution of $\left[\mathrm{Pd}(\mathrm{N}, \mathrm{C}-\mathrm{dmba})(\mathrm{MeCN})_{2}\right]\left(\mathrm{NO}_{3}\right)(\mathbf{1})(0.10 \mathrm{~g}, 0.26$ $\mathrm{mmol})$ in $5 \mathrm{~mL}$ of dichloromethane were added $0.042 \mathrm{~g}$ $(0.26 \mathrm{mmol})$ of 2-quinolinethiol $(\mathrm{qnSH})$ in $5 \mathrm{~mL}$ of dichloromethane. The solution was stirred for $1 \mathrm{~h}$; the solvent was then partially removed under reduced pressure and a dark orange solid was obtained by addition of pentane. The compound was filtered off, washed thoroughly with pentane and dried in vacuo. Recrystallization from a mixture of dichloromethane/ pentane (1:1) afforded a dark orange solid. Yield: $0.12 \mathrm{~g}$, 90\%. (Found.: C, 43.8; H, 3.45; N, 8.4. $\mathrm{C}_{18,5} \mathrm{H}_{20} \mathrm{~N}_{3} \mathrm{O}_{3} \mathrm{SClPd}$ calcd.: C, 43.9; $\mathrm{H}, 3.7 ; \mathrm{N}, 8.30 \%)$.

$[\mathrm{Pd}(\mathrm{N}, \mathrm{C}-\mathrm{dmba})(\mathrm{dppf})]\left(\mathrm{NO}_{3}\right)(4)$. To a solution of $0.10 \mathrm{~g}$
$(0.26 \mathrm{mmol})$ of $\left[\mathrm{Pd}(\mathrm{N}, \mathrm{C}-\mathrm{dmba})(\mathrm{MeCN})_{2}\right]\left(\mathrm{NO}_{3}\right)(\mathbf{1})$ in 15 $\mathrm{mL}$ of dichloromethane were added $0.14 \mathrm{~g}(0.26 \mathrm{mmol})$ of 1,1'-bis(diphenylphosphine)ferrocene (dppf) in $10 \mathrm{~mL}$ of dichloromethane. The mixture was stirred for $1 \mathrm{~h}$; the solvent was then partially removed under reduced pressure and addition of pentane afforded an orange solid. The solid was filtered off, washed thoroughly with pentane and dried in vacuo. Recrystallization from a mixture of dichloromethane/pentane (1:1) afforded an orange solid. Yield: 0.21g, 90\%. (Found C, 56.2; H, 4.5; N, 4.7. $\mathrm{C}_{43} \mathrm{H}_{40} \mathrm{~N}_{2} \mathrm{O}_{3} \mathrm{P}_{2}$ FePd calcd.: C, 56.2; H, 4.4; N, 4.5\%).

\section{Instrumental}

IR spectra were recorded on a NICOLET IMPACT 400 spectrophotometer in the $4000-400 \mathrm{~cm}^{-1}$ range with the samples in the form of $\mathrm{KBr}$ pellets. ${ }^{1} \mathrm{H},{ }^{13} \mathrm{C}$ and ${ }^{31} \mathrm{P}\left\{{ }^{1} \mathrm{H}\right\}$ NMR spectra were obtained in $\mathrm{CDCl}_{3}$ solutions using $\mathrm{SiMe}_{4}$ as the reference for the ${ }^{1} \mathrm{H}$ and ${ }^{13} \mathrm{C}$ NMR spectra and $85 \% \mathrm{H}_{3} \mathrm{PO}_{4}$ for the ${ }^{31} \mathrm{P}\left\{{ }^{1} \mathrm{H}\right\}$ NMR spectra. Thermogravimetric analyses (TG) were carried out under dynamic flow of dry synthetic air $\left(25 \mathrm{~mL} \mathrm{~min}^{-1}\right)$ and at a heating rate of $20{ }^{\circ} \mathrm{C} \mathrm{min}^{-1}$, using a TGS-2 Perkin-Elmer Thermoanalyser. The X-ray diffractograms were obtained with an HGZ 4/B horizontal diffractometer (G.D.R) equipped with a proportional counter and pulse height discriminator. The Bragg-Bretano arrangement was adopted using $\mathrm{CuK}_{\alpha}$ radiation $(\lambda=1.541 \AA$ ) and settings of $34 \mathrm{KV}$ and $20 \mathrm{~mA}$. The peaks were identified using ASTM data files.

\section{Results and Discussion}

\section{IR and NMR spectra}

Taking into account that cationic palladium(II) complexes containing weakly coordinated ligands such as $\mathrm{MeCN}$ are excellent precursors for further synthesis, we were motivated to perform the reactions of $[\mathrm{Pd}(\mathrm{N}, \mathrm{C}$ dmba)(MeCN$\left.)_{2}\right]\left(\mathrm{NO}_{3}\right)$ (1) with 3,5-dimethylpyrazole (Hdmpz), 2-quinolinethiol (qnSH) and 1,1'bis(diphenylphosphine)ferrocene (dppf) which afforded, respectively, $\left[\mathrm{Pd}(\mathrm{N}, \mathrm{C}-\mathrm{dmba})(\mathrm{Hdmpz})\left(\mathrm{ONO}_{2}\right)\right] 0.5 \mathrm{CH}_{2} \mathrm{Cl}_{2}$ (2), $\left[\mathrm{Pd}(\mathrm{N}, \mathrm{C}-\mathrm{dmba})(\mathrm{qnSH})\left(\mathrm{ONO}_{2}\right)\right] 0.5 \mathrm{CH}_{2} \mathrm{Cl}_{2}(3)$ and $\left.[\mathrm{Pd}(\mathrm{N}, \mathrm{C}-\mathrm{dmba})(\mathrm{dppf})]\left(\mathrm{NO}_{3}\right)\right](4)$, according to Scheme 1. The most important bands $\left(\mathrm{cm}^{-1}\right)$ observed in the IR spectra of 1-4 are given in Table 1 . The IR spectra show no $v_{\mathrm{CN}}$ bands due to the acetonitrile molecules, which are observed at 2308 and $2249 \mathrm{~cm}^{-1}$ in the IR spectrum of $\mathbf{1}$, indicating clearly their displacement by the Hdmpz, qnSH and dppf ligands. The presence of $v_{\text {NO }}$ bands at 1406 and $1315 \mathrm{~cm}^{-1}$ for 2 and at 1426 and $1334 \mathrm{~cm}^{-1}$ for 3 are 
characteristic of terminal monodentate nitrate group. ${ }^{12}$ On the other hand the IR spectrum of $\mathbf{4}$ shows $v_{\mathrm{NO}}$ and $\delta_{\mathrm{ONO}}$ bands at 1354 and $833 \mathrm{~cm}^{-1}$, respectively, which are consistent with an ionic nitrate group. ${ }^{12}$ Other important features that emerged from the analysis of the IR spectrum of 3 are the absence of a band near $2500 \mathrm{~cm}^{-1}$, typical ${ }^{13}$ of $v_{\mathrm{SH}}$, and the presence of bands at 3100, $v_{\mathrm{NH}}, 1618, v_{\mathrm{CC}} / v_{\mathrm{CN}}$; $1301, v_{\mathrm{C}=\mathrm{S}}+v_{\mathrm{C}=\mathrm{N}}+v_{\mathrm{CH}} ; 1148, v_{\mathrm{C}=\mathrm{S}} ; 1505, v_{\mathrm{CN}}, \mathrm{cm}^{-1}$. This data strongly suggests that qnSH is acting as a S-unidentate ligand which is in accordance with the soft character of both palladium and sulphur atoms.
Moreover, on the basis of the aforementioned discussion and considering that the coordination geometry around the palladium atom is square planar we suggest for complexes $\mathbf{2}, \mathbf{3}$ and $\mathbf{4}$ the structures shown in Scheme 1.

The ${ }^{1} \mathrm{H}$ and ${ }^{13} \mathrm{C}$ NMR spectra of the compounds 2,3 and 4, Table 2, give further evidence for the structural proposals outlined above. The ${ }^{1} \mathrm{H}$ NMR spectra reveal, in addition to the proton resonances of the dmba moiety, other signals characteristic of Hdmpz, qnSH and dppf coordinated to the palladium atom..$^{14}$ Although the overall pattern of the spectra is similar to that of the free ligands,

Table 1. IR spectral data $\left(\mathrm{cm}^{-1}\right)$ for compounds 1-4

\begin{tabular}{|c|c|c|c|c|c|}
\hline Compound & $v \mathrm{CN}$ & $v \mathrm{NO}$ & $\delta \mathrm{NO}$ & $v \mathrm{PC}$ & $v \mathrm{CC}_{\mathrm{Cp}}$ \\
\hline$\left[\mathrm{Pd}(\mathrm{N}, \mathrm{C}-\mathrm{dmba})(\mathrm{MeCN})_{2}\right]\left(\mathrm{NO}_{3}\right)(\mathbf{1})$ & $2308^{\mathrm{a}} \mathrm{w}, 2249^{\mathrm{a}} \mathrm{w}$ & $1387 \mathrm{vs}$ & $852 \mathrm{~m}$ & & \\
\hline$\left[\mathrm{Pd}(\mathrm{N}, \mathrm{C}-\mathrm{dmba})(\mathrm{Hdmpz})\left(\mathrm{ONO}_{2}\right)\right] 0.5 \mathrm{CH}_{2} \mathrm{Cl}_{2}$ (2) & $1580^{\mathrm{b}} \mathrm{m}, 1472^{\mathrm{b}} \mathrm{m}$ & $1406 \mathrm{vs}, 1315 \mathrm{vs}$ & $841 \mathrm{~m}, 801 \mathrm{~m}$ & & \\
\hline$\left[\mathrm{Pd}(\mathrm{N}, \mathrm{C}-\mathrm{dmba})(\mathrm{qnSH})\left(\mathrm{ONO}_{2}\right)\right] 0.5 \mathrm{CH}_{2} \mathrm{Cl}_{2}(3)$ & $1584^{\mathrm{b}} \mathrm{m}, 1505^{\mathrm{b}} \mathrm{m}$ & $1426 v s, 1334 s$ & $841 \mathrm{~m}, 801 \mathrm{~m}$ & & \\
\hline$[\mathrm{Pd}(\mathrm{N}, \mathrm{C}-\mathrm{dmba})(\mathrm{dppf})]\left(\mathrm{NO}_{3}\right)(\mathbf{4})$ & & $1354 \mathrm{vs}$ & $833 \mathrm{~m}$ & $1164 \mathrm{~m}$ & $1093 \mathrm{~m}$ \\
\hline
\end{tabular}

${ }^{\mathrm{a}}$ nitrile; ${ }^{\mathrm{b}}$ nitrogen ligand.

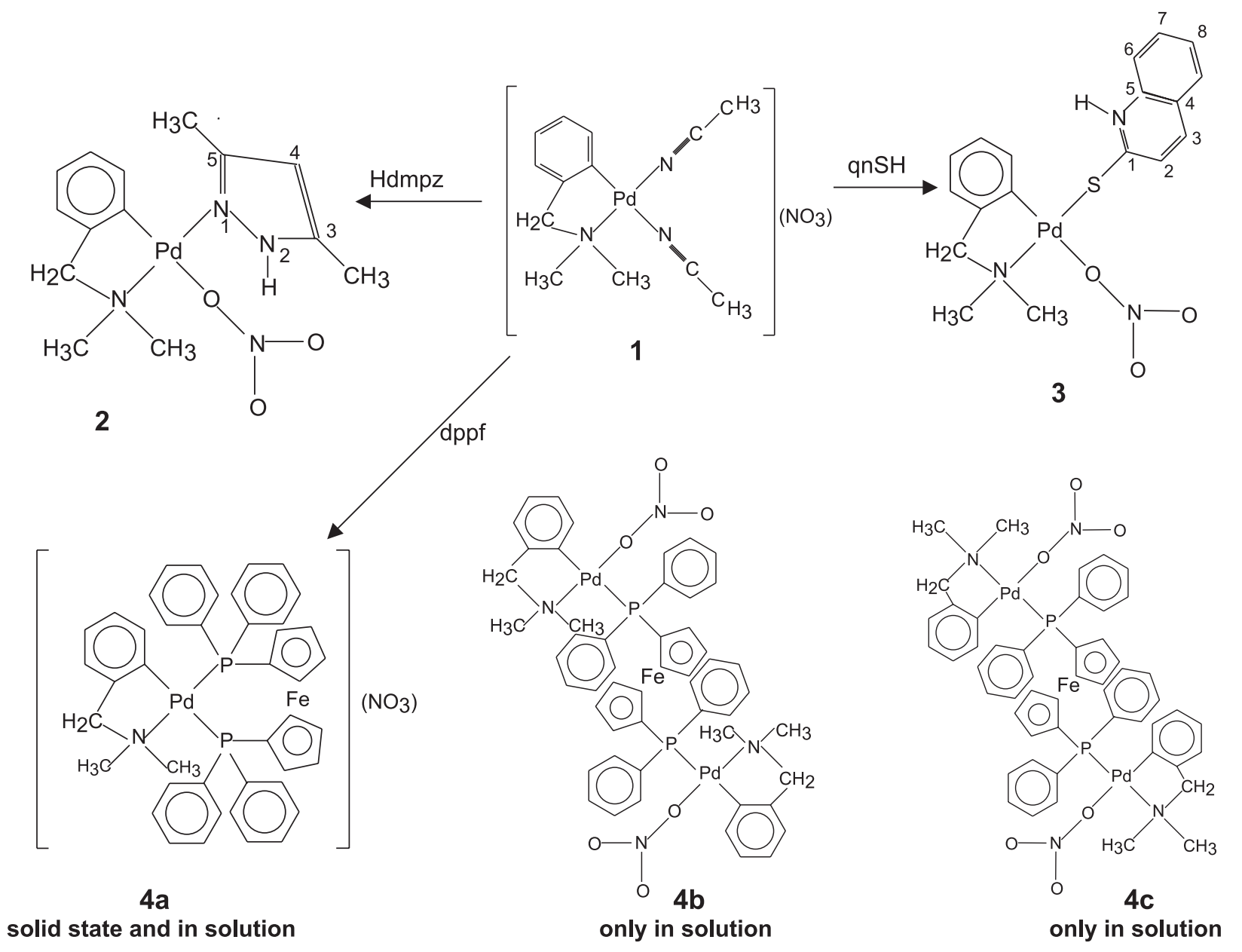


upon coordination all the signals shift to higher frequencies. ${ }^{14}$ Thus, for complex 2 the $\mathrm{H}(4),\left(3-\mathrm{CH}_{3}\right)$ and $\left(5-\mathrm{CH}_{3}\right)$ resonances appear as singlets at $\delta 5.69,2.97$ and 2.74, respectively, whereas for the free Hdmpz the signals are observed at $\delta 5.74[\mathrm{H}(4)]$ and $2.40\left(3-\mathrm{CH}_{3}\right.$ and $\left.5-\mathrm{CH}_{3}\right)$. The ${ }^{13} \mathrm{C}$ NMR spectrum of $\mathbf{2}$ exhibits the C(3) and C(5) signals at $\delta 14.0$ and 15.0, respectively, whereas these nuclei appear at $\delta 11.3$ and 12.9 in the spectrum of free Hdmpz.

The ${ }^{13} \mathrm{C}$ NMR spectrum of compound $\mathbf{3}$ exhibits the resonances of the quaternary carbon atoms of the qnSH ligand, namely $\mathrm{C}(4)$ and $\mathrm{C}(5)$, at $\delta 141.0$ and 122.0, respectively. In the case of complex 3 the two NMe groups appear to be diastereotopic as a result of a slow rotation around the Pd-S bond.

The ${ }^{1} \mathrm{H}$ NMR spectrum of $\mathbf{4}$ presents signals assigned to the $\mathrm{Cp}$ ring protons in the $\delta$ 5.27-3.96 range. The dmba $\left(-\mathrm{N}_{-} \mathrm{CH}_{2}-\right.$ ) resonance was shifted to higher frequency, being in this way hidden by the $\mathrm{Cp}$ protons resonances, and hence was not assigned. The ${ }^{13} \mathrm{C}$ NMR spectrum shows $\mathrm{Cp}$ ring resonances in the $\delta$ 76.5-72.3 range, and also in this case the $\left(-\mathrm{N}_{-} \mathrm{CH}_{2}{ }^{-}\right)$group resonance is hidden by those of the $\mathrm{Cp}$ ring.

Surprisingly the ${ }^{31} \mathrm{P}\left\{{ }^{1} \mathrm{H}\right\}$ NMR spectrum of $\mathbf{4}$ exhibits two singlets at $\delta 27.6$ and 27.1, and two doublets at $\delta 31.9$ and 12.7, of approximate relative intensities 1:2:2 thus suggesting the presence of three species in solution. The singlets are assigned to two structures in which the dppf acts as a bridging ligand, the compounds $\mathbf{4 b}$ and $\mathbf{4 c}$, while the two doublets are ascribed to another structure containing a chelating dppf molecule, the monomer $\mathbf{4 a}$, as shown in Scheme 1. The two dinuclear structures $\mathbf{4 b}$ and $\mathbf{4 c}$ differ with respect to the disposal of the ligands around the palladium atom: in $\mathbf{4 b}$, the dppf ligand is trans to the metallated carbon of dmba and the nitrate is trans to the nitrogen atom, whereas in $\mathbf{4 c}$ the dppf ligand is trans to the nitrogen atom of dmba and the nitrate is trans to the metallated carbon. Interestingly, the IR and microanalytical data, indicate the existence of only one species, $[\mathrm{Pd}(\mathrm{N}, \mathrm{C}-$ dmba)(dppf)] $\left.\left(\mathrm{NO}_{3}\right)\right](\mathbf{4 a})$, in the solid state.

\section{Thermogravimetric analyses}

The thermogravimetric analysis has been extensively employed in the study of coordination compounds but few papers have been published dealing with its use for the investigation of cyclopalladated compounds. In the present paper we used this technique to evidence the influence of the ligands coordinated to the palladium atom on the initial decomposition temperatures and on the thermal decomposition steps. The steps, initial and final temperatures $\left({ }^{\circ} \mathrm{C}\right)$, partial and total weight losses $(\%)$ for the decomposition of compounds 1-4 in dry air atmosphere, are given in Table 3 and in Figure 1.

The thermal degradation of $\mathbf{1}$ occurs in three steps. The first mass loss occurs between $85-180{ }^{\circ} \mathrm{C}$ and corresponds to, by mass calculation, the loss of two MeCN molecules. This fact is confirmed by the IR spectrum of the residue isolated at this stage that shows no bands assignable to the nitrile group. In the $180-336{ }^{\circ} \mathrm{C}$ range the mass loss is attributed to the elimination of the dmba group. The last step, in the $336-893{ }^{\circ} \mathrm{C}$ range, suggests the elimination of the nitrate group and the uptake of $\mathrm{O}_{2}$. The final residue was identified as PdO [ASTM card file 6-0515]. ${ }^{15}$ The IR spectra of the residues of each step confirmed the mass losses suggested. The TG curve of $\mathbf{2}$ indicates that its decomposition occurs in three steps. The first step, between 30-201 ${ }^{\circ} \mathrm{C}$, evidences the loss of a dichloromethane molecule, due to the peak at $61{ }^{\circ} \mathrm{C}$ in the dTG curve; the second step in the $201-282{ }^{\circ} \mathrm{C}$ range, suggests the loss of the dmba group. The third step, in the $282-894{ }^{\circ} \mathrm{C}$ range, is due to the elimination of the pyrazole ligand, a nitrate group and the uptake of $\mathrm{O}_{2}$. The final residue was identified as $\operatorname{Pd}(0)$ [ASTM card file 5-0681]. ${ }^{15}$ These data were

Table 2. NMR spectral data for compounds 1-4

\begin{tabular}{|c|c|c|c|c|c|c|c|c|}
\hline \multirow[t]{2}{*}{ Compound } & \multirow[b]{2}{*}{ C-Pd } & \multirow[b]{2}{*}{$-\mathrm{N}-\mathrm{CH}_{2}-$} & \multicolumn{3}{|l|}{${ }^{13} \mathrm{C}$ NMR } & \multicolumn{2}{|l|}{${ }^{1} \mathrm{H}$ NMR } & \multirow[t]{2}{*}{${ }^{31} \mathrm{P}\left\{{ }^{1} \mathrm{H}\right\} \mathrm{NMR}$} \\
\hline & & & {$\left[-\mathrm{N}\left(\mathrm{CH}_{3}\right)_{2}\right]$} & $\mathrm{C}_{\text {arom. }}$ & $\mathrm{H}_{\text {arom. }}$ & $-\mathrm{N}-\mathrm{CH}_{2}-$ & {$\left[-\mathrm{N}\left(\mathrm{CH}_{3}\right)_{2}\right]$} & \\
\hline$\left[\mathrm{Pd}(\mathrm{N}, \mathrm{C}-\mathrm{dmba})(\mathrm{MeCN})_{2}\right]\left(\mathrm{NO}_{3}\right)(\mathbf{1})$ & 146.9 & 72.9 & 51.6 & 140.4-121.9 & $7.08-6.94 \mathrm{~m}$ & $3.91 \mathrm{~s}$ & $2.78 \mathrm{~s}$ & \\
\hline $\begin{array}{l}{\left[\mathrm{Pd}(\mathrm{N}, \mathrm{C}-\mathrm{dmba})(\mathrm{Hdmpz})\left(\mathrm{ONO}_{2}\right)\right]} \\
0.5 \mathrm{CH}_{2} \mathrm{Cl}_{2} \text { (2) }\end{array}$ & 147.4 & 73.5 & 51.8 & $143.3-105.0$ & $7.18-6.08 \mathrm{~m}$ & $5.76 \mathrm{~d}$ & $2,70 \mathrm{~s}$ & \\
\hline $\begin{array}{l}{\left[\mathrm{Pd}(\mathrm{N}, \mathrm{C}-\mathrm{dmba})(\mathrm{qnSH})\left(\mathrm{ONO}_{2}\right)\right]} \\
0.5 \mathrm{CH}_{2} \mathrm{Cl}_{2}(\mathbf{3})\end{array}$ & 147.9 & 72.7 & $52.0,51.5$ & $141.0-117.0$ & $8.48-6.58 \mathrm{~m}$ & $3.92 \mathrm{~s}$ & $\begin{array}{l}2.97 \mathrm{~s} \\
2.67 \mathrm{~s}\end{array}$ & \\
\hline$[\mathrm{Pd}(\mathrm{N}, \mathrm{C}-\mathrm{dmba})(\mathrm{dppf})]\left(\mathrm{NO}_{3}\right)$ & 147.9 & & 49.8 & $137.2-123.2$ & $7.64-6.33 m$ & & $\begin{array}{l}2.69 \mathrm{~s} \\
2.31 \mathrm{~s}\end{array}$ & $\begin{array}{l}27.6 \mathrm{~s}, 27,1 \mathrm{~s} \\
31.9,12.7 \mathrm{~d} \\
J_{\mathrm{pp}} 30 \mathrm{~Hz}\end{array}$ \\
\hline
\end{tabular}

$\delta 120.0$ and 51.6, $-\mathrm{NCCH}_{3}\left({ }^{13} \mathrm{C} \mathrm{NMR}\right)$ and $\delta 2.78$ and $2.36,-\mathrm{NCCH}_{3}\left({ }^{1} \mathrm{H}\right.$ NMR) for $\left[\mathrm{Pd}(\mathrm{N}, \mathrm{C}-\mathrm{dmba})(\mathrm{MeCN}){ }_{2}\right]\left(\mathrm{NO}_{3}\right)(\mathbf{1}) ; \delta 141.0$ and 122.0 for $\mathrm{C}(4)$ and $\mathrm{C}(5)$, respectively, for $\left[\mathrm{Pd}(\mathrm{N}, \mathrm{C}-\mathrm{dmba})(\mathrm{qnSH})\left(\mathrm{ONO}_{2}\right)\right] 0.5 \mathrm{CH}_{2} \mathrm{Cl}_{2}(3)$. 

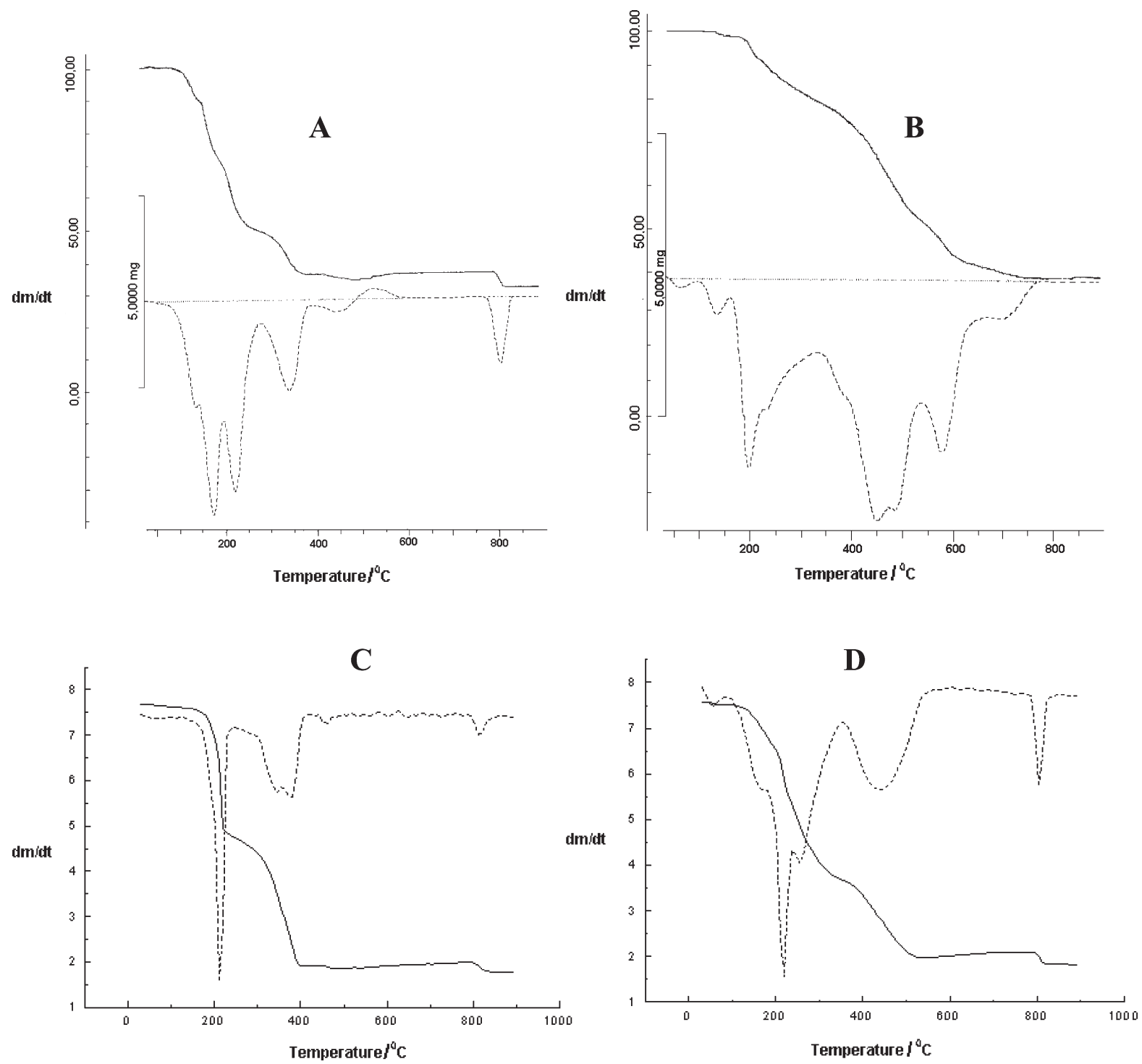

Figure 1. TG(-) and dTG(- - ) curves of compounds: (A) $\left[\mathrm{Pd}(\mathrm{N}, \mathrm{C}-\mathrm{dmba})(\mathrm{MeCN})_{2}\right]\left(\mathrm{NO}_{3}\right)(\mathbf{1})$; (B) $\left.[\mathrm{Pd}(\mathrm{N}, \mathrm{C}-\mathrm{dmba})(\mathrm{dppf})](\mathrm{NO})_{3}\right)(\mathbf{4})$; $(\mathrm{C})$ $\left[\mathrm{Pd}(\mathrm{N}, \mathrm{C}-\mathrm{dmba})(\mathrm{Hdmpz})\left(\mathrm{ONO}_{2}\right)\right] 0.5 \mathrm{CH}_{2} \mathrm{Cl}_{2}(\mathbf{2})$ and $(\mathrm{D})\left[\mathrm{Pd}(\mathrm{N}, \mathrm{C}-\mathrm{dmba})(\mathrm{qnSH})\left(\mathrm{ONO}_{2}\right)\right] 0.5 \mathrm{CH}_{2} \mathrm{Cl}_{2}(\mathbf{3})$.

Table 3. Thermal analysis for compounds 1-4

\begin{tabular}{|c|c|c|c|c|}
\hline Compound & Step & $\mathrm{T}_{\mathrm{i}} /{ }^{\circ} \mathrm{C}$ & $\mathrm{T}_{\mathrm{f}} /{ }^{\circ} \mathrm{C}$ & $\Delta \mathrm{m} / \%$ \\
\hline \multirow[t]{3}{*}[\mathrm{Pd}(\mathrm{N},\mathrm{C}-\mathrm{dmba})(\mathrm{MeCN})_{2}]{$\left(\mathrm{NO}_{3}\right)(\mathbf{1})$} & 1 & 85 & 180 & 21.81 \\
\hline & 2 & 180 & 336 & 35.00 \\
\hline & 3 & 336 & 893 & $\begin{array}{l}12.33 \\
(69.14)\end{array}$ \\
\hline \multirow[t]{3}{*}[\mathrm{Pd}(\mathrm{N},\mathrm{C}-\mathrm{dmba})(\mathrm{Hdmpz})(\mathrm{ONO}_{2})]{$0.5 \mathrm{CH}_{2} \mathrm{Cl}_{2}(2)$} & 1 & 30 & 201 & 13.75 \\
\hline & 2 & 201 & 282 & 28.93 \\
\hline & 3 & 282 & 894 & $\begin{array}{l}34.25 \\
(76.93)\end{array}$ \\
\hline \multirow[t]{4}{*}[\mathrm{Pd}(\mathrm{N},\mathrm{C}-\mathrm{dmba})(\mathrm{qnSH})(\mathrm{ONO}_{2})]{$0.5 \mathrm{CH}_{2} \mathrm{Cl}_{2}(3)$} & 1 & 30 & 170 & 8.09 \\
\hline & 2 & 170 & 255 & 26.79 \\
\hline & 3 & 255 & 462 & 31.60 \\
\hline & 4 & 462 & 894 & $\begin{array}{l}9.48 \\
(75.96)\end{array}$ \\
\hline \multirow[t]{2}{*}[\mathrm{Pd}(\mathrm{N},\mathrm{C}-\mathrm{dmba})(\mathrm{dppf})]{$\left(\mathrm{NO}_{3}\right)$} & 1 & 108 & 292 & 6.32 \\
\hline & 2 & 292 & 900 & $\begin{array}{l}55.94 \\
(62.10)\end{array}$ \\
\hline
\end{tabular}


confirmed by the IR spectra of the residues of each step. The thermal decomposition of $\mathbf{3}$ shows that the degradation occurs in four steps. The first step, in the $30-170{ }^{\circ} \mathrm{C}$ range, is assigned to loss of a dichloromethane molecule. The second step, $170-255^{\circ} \mathrm{C}$, comprises the elimination of the dmba group and the third step, $255-462{ }^{\circ} \mathrm{C}$, suggests the elimination of aromatic rings of the qnSH ligand. Finally, the last step, $462-894{ }^{\circ} \mathrm{C}$, corresponds to the elimination of the nitrate group and the uptake of $\mathrm{O}_{2}$. The final residue is suggested to be $\mathrm{Pd}_{2} \mathrm{OSO}_{4}$. The X-ray diffractogram of this residue showed the following interplanar distance values d(hkl)(\%): 9.64(35); 7.37(33); 5.26(32); 5.07(34); 3.91(40); 3.53(41); 3.03(43); 2.84(45); 2.65(64); 2.57(32); $2.54(32) ; 2.25(100) ; 1.95(80) ; 1.56(32) ; 1.49(39)$; $1.46(50) ; 1.45(32)$ e $1.39(37) \AA$. The TG curve of 4 shows that its decomposition occurs in two consecutive steps. The first step, in the $108-292{ }^{\circ} \mathrm{C}$ range, is assigned to the elimination of the dmba group and the second step, in the 292-900 ${ }^{\circ} \mathrm{C}$ range, comprises the elimination of the dppf and nitrate groups, and the uptake of $\mathrm{O}_{2}$. The residue was identified as a mixture of $\mathrm{PdO}$ and $\mathrm{Fe}_{2}\left(\mathrm{PO}_{4}\right)_{3}$ [ASTM card file 14-337]. ${ }^{15}$ The IR spectra of the residues of each step confirm the mechanism proposed. Considering the initial temperature of the thermal decomposition processes, it is possible to establish the following relative thermal stability order: $\mathbf{2}>\mathbf{3}>\mathbf{4}>\mathbf{1}$. The lower stability of $\mathbf{1}$ can be explained by the presence of weakly coordinated acetonitrile ligands.

\section{Conclusions}

The acetonitrile molecules of $\mathbf{1}$ are easily displaced by ligands such as 3,5-dimethylpyrazole (Hdmpz), 2quinolinethiol (qnSH), 1,1'-bis(diphenylphosphine) ferrocene (dppf) affording mononuclear products. The solid state IR spectra clearly indicate the presence of a monodentate nitrate ligand in compounds $\mathbf{2}$ and $\mathbf{3}$ and of an ionic nitrate in 4. In solution, however, ${ }^{31} \mathrm{P}\{\mathrm{H}\}$ NMR spectroscopy indicates that compound $\mathbf{4}$ exists in three forms: $\mathbf{4 a}$, in which the dppf ligand acts as a chelate, and $\mathbf{4 b}$ and $\mathbf{4 c}$, in which it acts as a bridging ligand.

The thermal analysis data will be of great importance notably for further applications of these complexes in homogeneous catalysis processes such as in the carbonylation of amines to ureas or carbamates, currently under investigation in our laboratory.

\section{Acknowledgements}

The authors wish to acknowledge CNPq, FAPESP and CAPES for partial financial support.

\section{References}

1. Shilov, A.E.; Shul'pin, G.B.; Chem. Rev. 1997, 97, 2879; Arndtsen, B. A.; Bergman, R.G.; Morley, T.A.; Peterson, T. H.; Acc. Chem. Res. 1995, 28, 154; Cámpora, J.; López, J. A.; Palma, P.; Valerga, P.; Spillnes, E.; Carmona, E.; Angew. Chem. Int. Ed. 1999, 38, 147.

2. Cámpora, J.; Palma, P.; Carmona, E.; Coord. Chem. Rev. 1999, 193-195, 207; de Geest, D.J.; O’Keefe, B. J.; Stell, P.J.; J. Organomet. Chem. 1999, 579, 97.

3. Albert, J.; Bosque, R.; Granell, J.; Tavera, R.; J. Organomet. Chem. 2000, 595, 54; Terjido, B.; Fernández, A.; Torres, M. L.; Juiz, S.C.; Suárez, A.; Ortigueira, J.M.; Vila, J. M.; Fernández, J. J.; J. Organomet. Chem. 2000, 598, 71; Fuchita, Y.; Yoshinaga, K.; Hanaki, T.; Kawano, H.; Nagaoka, J. K.; J. Organomet. Chem. 1999, 580, 273; Cui, X. L.; Wu, Y. J.; Du, C. X.; Yang, L. R.; Zhu, Y.; Tetrahedron Asymmetry 1999, 10, 1255.

4. Zhao, G.; Wang, Q.G.; Mak, T.C.W.; J. Organomet. Chem. 1999, 574, 311; Bento, M.; López, C.; Solans, X.; Font-Bardía, M.; Tetrahedron Asymmetry 1998, 9, 4219; Ryabov, A. D.; van Eldik, R.; Le Borgne, G.; Pfeffer, M.; Organometallics 1993, 12, 1386; Tollari, S.; Cenini, S.; Tunice, C.; Palmisano, G.; Inorg. Chim. Acta 1998, 272, 18.

5. Buey, J.; Espinet., P.; J. Organomet. Chem. 1996, 507, 137; Cave, G. W. V.; Lydon, D. P.; Rourke, J. P.; J. Organomet. Chem.1998, 555, 81; Godquin, A. M. G.; Coord. Chem. Rev. 1998, 178-180, 1485; Saccomando, D. J.; Black, C.; Cave, G. W. V.; Lydon, D. P.; Rourke, J. R.; J. Organomet. Chem. 2000, 601, 305 .

6. von Zelewsky, A.; Belser, P.; Hayoz, P.; Dux, R.; Hua, X.; Suckling, A.; Stoeckli-Evans, H.; Coord. Chem. Rev. 1994, 132, 75 .

7. Kurzeev, S. A.; Kazankov, G.M.; Ryabov, A. D.; Inorg. Chim. Acta 2000, 305, 1; Zim, D.; Gruber, A.S.; Ebeling, G.; Dupont, J.;. Monteiro, A.; Org. Lett. 2000, 2, 2881; Dupont, J.; Pfeffer, M.; Spencer, J.; Eur. J. Inorg. Chem. 2001, 1917; Dupont, J.; Gruber, A.S.; Fonseca, G.S.; Monteiro, A.L.; Ebeling, G.; Burrow, B.A.; Organometallics 2001, 20, 171.

8. Higgius, J. D.; J. Inorg. Biochem. 1993, 49, 149; NavarroRanninger, C.; López-Solera, I.; González, V. M.; Pérez, J. M.; Alvarez-Valdéz, A.; Martín, A.; Raithby, P. R.; Masaguer, J. R.; Alonso, C.; Inorg. Chem. 1996, 35, 5181; Zamora, F.; González, V.M.; Pérez, J. M.; Masaguer, J. R.; Alonso, C.; NavarroRanninger, C.; Appl. Organomet. Chem. 1997, 11, 659.

9. de Lucca Neto, V. A.; Mauro, A. E.; Caires, A. C.F.; Ananias, S. R.; de Almeida, E. T.; Polyhedron 1999, 18, 413; Mauro, A.E.; Caires, A.C.F.; Santos, R.H.A.; Gambardella, M.T.P.; J. Coord.Chem. 1999, 48, 521; Caires, A.C.F.; de Almeida, E.T.; Mauro, A.E.; Hermely, J.P.; Valentini, S.; Quim. Nova 1999, 22, 329; Ananias, S. R.; Mauro, A. E.; de Lucca Neto, V. A.; Transition Metal Chem. 2001, 26, 570. 
10. Kim, T.J.; Kwon, K.H.; Kwon, S.C.; Baeg, J.O.; Shim, S.; J. Organomet. Chem. 1999, 389, 205; Scarcia, V.; Furlani, A.; Longato, B.; Corain, B.; Pilloni, G.; Inorg. Chim. Acta 1998, 153, 67-79; Sadimenko, A.P.; Basson, S.S.; Coord. Chem. Rev. 1996, 147, 247; Ardizzoia, G.A.; Cenini, S.; La Monica, G.; Masciocchi, N.; Moret, M.; Inorg. Chem. 1994, 33, 1458; Raper, E.S.; Coord. Chem. Rev. 1985, 61, 115.

11. Ananias, S. R.; Mauro, A. E.; Nogueira, V. M.; Haddad P. S.; de Almeida, E.T.; Eclet. Quim. 2001, 26, 87.

12. Nakamoto, K.; Infrared and Raman Spectroscopy of Inorganic and Coordination Compounds, Wiley Interscience: New York, 1986.
13. Rapper, E. S.; Coord. Chem. Rev. 1997, 165, 475.

14. Silverstein, R. M.; Basslerk, G. C.; Morrill, T. C.; Spectrometry Identification of Organic Compounds, $4^{\text {th }}$ ed., Wiley Interscience: New York ,1981.

15. Powder Diffraction File of the Joint Committee on Power Diffraction Standards, published by the International Center of Diffraction Data, Swarthmore, PA, USA, 19081, 1982.

Received: September 17, 2002

Published on the web: August 12, 2003

FAPESP helped in meeting the publication costs of this article. 